Milk hormone faces new hurdles on way to market States, worried that milk may lose its 'pure' image through being associated with genetic engineering, are hesitating before adopting the widespread use of bovine somatotropin (BST), the hormone that can increase yields by up to 25 per cent.

The US Food and Drug Administration announced on 5 November, after nine years of review, that it had decided that bovine somatotropin is safe and effective, and could be sold to dairy farmers. But it is imposing a 90-day moratorium before BST goes on sale, and this together with years of controversy and the continued opposition of groups of farmers, remain a challenge for Monsanto Co., which has developed the hormone treatment for increasing yields.

The hormone has led to demands from consumer groups for genetically engineered foods to be labelled as such, and to declarations by dairy companies that they will not sell milk from cows treated with BST. Activists have promised to organize boycotts and demonstrations against the product

Surveys have shown that between 15 and 40 per cent of consumers are likely to stop or reduce their milk consumption if farmers begin to use BST. Such surveys have prompted many dairy buyers to decide not to sell BST-generated milk. The California Milk Advisory Board, for example, a marketing coalition for the biggest dairy state in the nation, recommends that dairy farmers
San Francisco. Dairy farmers in the United

not use the drug.

A number of dairy produce companies have said they will not accept milk from cows treated with BST. Several may label their milk as 'BST-free', even though they admit it will be hard to monitor use of the drug by their suppliers. Three major drug companies promised earlier this year not to use the hormone in their infant formulas.

Monsanto, however, claims that many farmers want its product, according to Tom McDermott, a spokesman for the company Monsanto plans to use the 90-day period before the hormone goes on sale to convince opinion leaders among animal nutritionists, veterinarians and dairy farmers of its value.

As the drug clears regulatory hurdles, the debate surrounding its use may shift from safety to economics. BST will not actually be sold until February because of the moratorium, set by Congress to allow the White House to study the potential economic impact of the treatment, including its impact on small dairy farms.

Russ Feingold, a Democrat Senator from Wisconsin who was responsible for the bill imposing the moratorium, said he intends to use the study to ask President Clinton to extend the moratorium, to enact a labelling rule, or to tax dairy farmers who use BST. Such a tax would be justified, he said, because of the costs to government of buying up unsold milk.

Sally Lehrman

\section{UK report criticizes plan for PhDs}

London. Proposals by the British government to introduce a mandatory masters qualification as part of the $\mathbf{P h D}$ degree were criticized in a report issued this week by the National Commission on Education, a body set up two years ago at the suggestion of Sir Claus Moser, then president of the British Association for the Advancement of Science (BA).

The proposal was made in the recent white paper on science, published in May. But the commission says that, since the government does not intend to provide any more money for the revised research degrees, the number of students taking doctoral courses will inevitably fall. This will increase the difficulty UK universities already face in employing researchers at rates competitive with industry, or with universities in other countries.

Recommendations made by the commission include increasing the number of graduate schools in universities, raising the morale of academic researchers by improving pay and career structures, and providing training skills to university lecturers, most of whom have no formal training in teaching.

The commission also calls for a proper financial strategy for future expansion, worked out between the government and the higher-education institutions. It says that the money to support such expansion cannot continue to come primarily from gains in efficiency, as it has done over the past decade or so; it suggests that its recommendations are funded through greater contributions from both industry and students.

The recommendations are part of the commission's two-year, independent review of education and training in Britain. The study was initiated by the BA in the light of serious shortcomings in education and training standards, particularly in comparison with other European countries, and the refusal of the government to set up its own study. Maxine Clarke * Learning to Succeed National Commission on Education, Heinemann, $£ 4.99$
Protest group turns spotlight on university researcher

Munich. Animal rights activists have placed the name, address and telephone number of a university neuroscientist on a large billboard in the centre of Munich, following the decision of a newly-appointed ethics committee to overturn the ruling of an earlier committee not to approve experiments that she had proposed on primates.

The animal rights group also distributed leaflets in the researcher's home village describing scientists who use animals in their research as criminals who should not remain anonymous. Police ordered the removal of a black cross - a sign of death which had been painted over the billboard.

The researcher involved is Jean-Alice Büttner-Ennevener, a professor of neuropathology at Ludwig Maximilian University. She has since received many death threats. A spokeswoman for the animal rights group, Tierversuchsgegner München, said that the group would go as far as it could, short of actually harming people, to achieve its goal of abolishing the use of animals in biomedical research.

Representatives from the university, its physiological institute and its neurological clinic have all come to Büttner-Ennevener's defence. Further support has come from patients who have benefitted from her research, which has led to a method of identifying nerve pathways responsible for balance and eye movement disturbances following stroke.

Her research is supported as a 12-year 'special research programme' by the Deutsche Forschungsgemeinschaft. Last summer, an ethics commission reversed previous decisions that had been regularly taken to approve her work. But this decision has now itself been overturned.

The animal rights group says that singling out scientists for a personal campaign is an effective form of protest. "We want to give [animal researchers] sleepless nights", says the spokeswoman.

The incident is one of several in Germany in the past few years, even though the number of animals used in medical research has fallen. In 1989, 2.64 million animals were used in the old Länder alone; in contrast, the total number used last year in the whole of Germany was 2.08 million.

Meanwhile, research scientists with the British pharmaceutical company Glaxo are also being targeted by an animal rights group. The Animal Rights Militia has claimed responsibility for a series of incidents designed to dissuade researchers from joining the company's new research complex at Stevenage, including sending a hoax bomb to the home of one employee.

Alison Abbott 